\title{
ANTIFUNGAL, ANTIBACTERIAL AND ANTIOXIDANT COMPONENTS OF ETHYL ACETATE EXTRACT OF QUINOA STEM
}

Iqra Haider Khan, Arshad Javaid

Institute of Agricultural Sciences, University of the Punjab, Lahore, Pakistan.

ART I C L E I N F O

\begin{tabular}{l} 
Article history \\
Received: June 12, 2019 \\
Revised: September 24, 2019 \\
Accepted: December 15, 2019 \\
\hline Keywords \\
Antifungal \\
Antibacterial \\
Ethyl acetate fraction \\
Quinoa
\end{tabular}

A B S T R A C T

Quinoa (Chenopodium quinoa L.) is a recently introduced pseudocereal crop in Pakistan. In the present study, methanolic extract was partitioned with $n$-hexane, chloroform and finally with ethyl acetate. The ethyl acetate fraction was subjected to GC-MS analysis for the identification of various antimicrobial and antioxidant constituents. Thirteen compounds were identified through GC-MS analysis of this fraction. Among these, 11 compounds possessed antibacterial, antifungal and/or antioxidant properties as reported in literature. These include naphthalene; tetradecane; hexadecane; pentadecane; cyclohexadecane; 1,2-benzenedicarboxylic acid, bis(2-methylpropyl) ester; dibutyl phthalate; 1-nonadecene; 1-octadecanol; 9hexacosene; and 1,2-benzenedicarboxylic acid, mono(2-ethylhexyl) ester.

Corresponding Author: Arshad Javaid

Email: arshad.iags@pu.edu.pk

(c) 2019 EScience Press. All rights reserved.

\section{INTRODUCTION}

The use of plant products is an old-age practice for the treatment of infectious diseases and pathogens. Interest in plant products has been revived again due to the hazardous effects of chemical products in contrast with natural plant derived products which are safe in use, environment friendly and have low cost. Currently, in Asian and African countries, $80 \%$ of the population depends upon folk medicines prepared from traditional phytochemicals isolated from plants being used in healthcare products, medicines, pesticides and fungicides (Pereira et al., 2017). In general, plants are a rich source of secondary metabolites with enormous chemical diversity possessing antifungal, antibacterial, antimicrobial, antioxidant and nematicidal properties (Waltenberger et al., 2018). Some of them are constitutive and exist only in their bioactive forms whereas many others are responded as inactive precursors in response to pathogenic attacks. Well known examples of constitutive phytochemicals are spermidine, coumarins, alkaloids, carotenoids, flavonoids, terpenes, tocopherol, campesterol, kaempferol, sesquiterpenes, quercetin, triterpenoids, polyphenols, glycosides, rutin, phenols, lactones, saponins and glucosinolates (Meela et al., 2019).

Chenopodium quinoa Willd. is a multipurpose agroindustrial pseudo grain native to Andean regions and cultivated thousands of years ago. Because of nutritional characteristics and wide ability to stress tolerance against drought and saline soils, it has justified the cultivation interest not only in Pakistan but worldwide. Many other countries like Europe, China, India, Canada and Columbia are increasing their demand towards quinoa (Gámez et al., 2019). It is a short duration high yielding crop that can also be used as a break crop because of resistance to pathogens. It is rich in minerals, 
lysine, amino acid and gluten free making it a more valuable crop than others (Vergara et al., 2019). Quinoa seed coat contains saponins, glycosides and triterpenoids making it bitter in taste. It also possesses diverse bioactive constituents which are antifungal, antibacterial, antioxidant and antimicrobial in nature (Maliro and Njala, 2019). Therefore, the current study was aimed to elucidate the phytoconstituents present in ethyl acetate stem extract of quinoa.

\section{MATERIALS AND METHODS}

Quinoa accession Ames 13737, New Mexico USA, was sown in November 2017 for the collection of plant material and uprooted at plant maturity. Stem $(2 \mathrm{~kg})$ was washed under tap water in order to remove unwanted soil particles and debris. The fresh cleaned material was then dried under shade and chopped down in order to prepare a homogenized mixture using a mechanical grinder. Methanolic extract of the powder was obtained by maceration in methanol $(5 \mathrm{~L})$ for two weeks followed by filtration with Whatman No.1 filter paper. Next, the solvent was evaporated under vacuum at $45^{\circ} \mathrm{C}$ to obtain concentrated material and stirred in distilled water. After that, the obtained biomass was mixed with $200 \mathrm{~mL}$ water and successively partitioned with $n$-hexane, chloroform and finally with ethyl acetate in a separating funnel (Akhtar and Javaid, 2018). The ethyl acetate fraction was subjected to GC-MS analysis for the evaluation of bioactive constituents. GC-MS analysis was conducted using a chromatographic system comprised of a Shimadzu GC-2010plus installed with auto injector AOC-20i, auto sampler AOC-20s and gas chromatograph equipped with a QP2010ultra massselective detector (Shimadzu).

\section{RESULTS AND DISCUSSION}

GC-MS analysis of ethyl acetate fraction of methanolic stem extract is given in Figure 1 which indicates the presence of 13 constituents belonging to a diverse group of natural volatile organic compounds. Details of identified compounds are presented in Table 1 and structures of these identified compounds are shown in Figure 2. The major prevailing phytochemical constituents were benzene, nitro (2) and 1,2benzenedicarboxylic acid, mono(2-ethylhexyl) ester (13) with peak areas of $28.28 \%$ and $12.01 \%$, respectively. The compounds namely naphthalene (3), 1-nonadecene (10), dibutyl phthalate (9), 9-hexacosene (12) and cyclohexadecane (6) showing abundance at peak areas of $9.31,8.27,5.16,4.35$ and $4.11 \%$, respectively were recorded as moderate ones. On the other hand, the compounds present in less concentrations were phenol, 3-methyl (1), 1,2-benzenedicarboxylic acid, bis(2methylpropyl) ester (8), hexadecane (7), pentadecane (5), tetradecane (4) and 1-octadecanol (11) with peak areas ranging from 1.70 to $2.79 \%$.

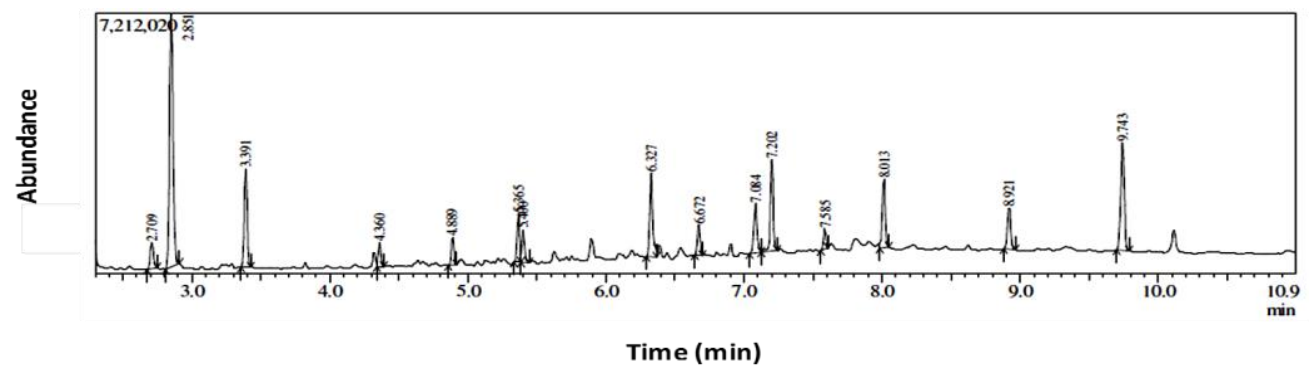

Figure 1. GC-MS chromatograms of ethyl acetate fraction of methanolic stem extract of Chenopodium quinoa.

The most abundant compound 13 was previously identified by Deepak et al. (2017) from $n$-hexane extract of Turbinaria ornata and is known to possess antimicrobial properties against Bacillus subtilis, Escherichia coli, Aspergillus niger, Pseudomonas aeruginosa and Candida albicans. This compound is also known for its antiviral, antioxidant, anticancer and antiinflammatory properties. Likewise, compound 3 was previously isolated from Zingiber officinale with a strong antioxidant and inhibitory efficacy against Klebsiella pneumonia, Staphylococcus aureus, Proteus mirabilis, $P$. aeruginosa, E. coli and Proteus mirabilis (Shareef et al., 2016). Similarly, compounds 10, 11 and 12 were also reported to possess strong antibacterial and antifungal efficacy against human pathogenic bacterial species including E. coli, P. aeruginosa, Streptococcus mutans, B. circulans and $S$. aureus as well as fungal pathogens namely Sclerotinia sclerotiorum, Fusarium oxysporum, Botrytis cinerea and Rhizoctonia solani (Balachandar et al., 2018; Servi et al., 2019). 


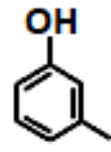

1. Phenol,3-methyl-

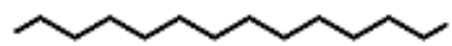

4. Tetradecane

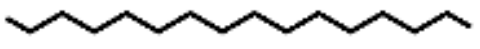

7. Hexadecane

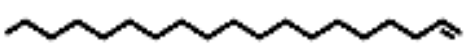

10. 1-Nonadecene

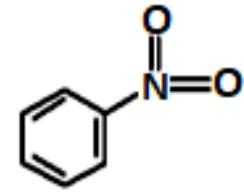

2. Benzene, nitro-

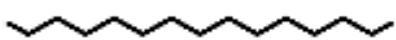

5. Pentadecane

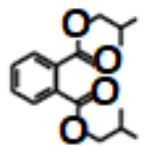

8. 1,2-Benzenedicarboxylic acid, bis(2-methylpropyl) ester

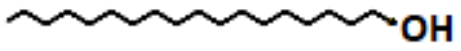

11. 1-Octadecanol

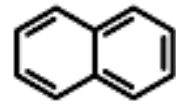

3. Naphthalene

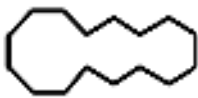

6. Cyclohexadecane

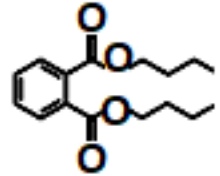

9. Dibutyl phthalate

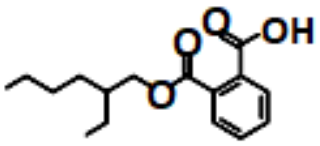

13. 1,2-Benzenedicarboxylic acid, mono(2-ethylhexyl) ester

Figure 2. Structures of compounds identified in ethyl acetate fraction of stem extract of Chenopodium quinoa through GC-MS.

Table 1. List of compounds in ethyl acetate fraction of methanolic stem extract of Chenopodium quinoa identified by GC-MS analysis.

\begin{tabular}{|c|c|c|c|c|c|}
\hline Sr. No. & Names of compounds & Molecular formula & Molecular weight & $\begin{array}{l}\text { Retention } \\
\text { time (min) }\end{array}$ & $\begin{array}{c}\text { Peak area } \\
(\%)\end{array}$ \\
\hline 1 & Phenol,3-methyl- & $\mathrm{C}_{7} \mathrm{H}_{8} \mathrm{O}$ & 108 & 2.709 & 2.79 \\
\hline 2 & Benzene, nitro- & $\mathrm{C}_{6} \mathrm{H}_{5} \mathrm{NO}_{2}$ & 123 & 2.851 & 28.28 \\
\hline 3 & Naphthalene & $\mathrm{C}_{10} \mathrm{H}_{8}$ & 128 & 3.391 & 9.31 \\
\hline 4 & Tetradecane & $\mathrm{C}_{14} \mathrm{H}_{30}$ & 198 & 4.360 & 1.95 \\
\hline 5 & Pentadecane & $\mathrm{C}_{15} \mathrm{H}_{32}$ & 212 & 4.889 & 2.30 \\
\hline 6 & Cyclohexadecane & $\mathrm{C}_{16} \mathrm{H}_{32}$ & 224 & 5.365 & 4.11 \\
\hline 7 & Hexadecane & $\mathrm{C}_{16} \mathrm{H}_{34}$ & 226 & 5.400 & 2.52 \\
\hline 8 & $\begin{array}{l}\text { 1,2-Benzenedicarboxylic acid, } \\
\text { bis(2-methylpropyl) ester }\end{array}$ & $\mathrm{C}_{16} \mathrm{H}_{22} \mathrm{O}_{4}$ & 278 & 6.672 & 2.63 \\
\hline 9 & Dibutyl phthalate & $\mathrm{C}_{16} \mathrm{H}_{22} \mathrm{O}_{4}$ & 278 & 7.084 & 5.16 \\
\hline 10 & 1-Nonadecene & $\mathrm{C}_{19} \mathrm{H}_{38}$ & 266 & 7.202 & 8.27 \\
\hline 11 & 1-Octadecanol & $\mathrm{C}_{18} \mathrm{H}_{38} \mathrm{O}$ & 270 & 7.585 & 1.70 \\
\hline 12 & 9-Hexacosene & $\mathrm{C}_{26} \mathrm{H}_{52}$ & 364 & 8.921 & 4.35 \\
\hline 13 & $\begin{array}{l}\text { 1,2-Benzenedicarboxylic acid, } \\
\text { mono(2-ethylhexyl) ester }\end{array}$ & $\mathrm{C}_{16} \mathrm{H}_{22} \mathrm{O}_{4}$ & 278 & 9.743 & 12.01 \\
\hline
\end{tabular}


Table 2. Bioactivity of compounds in ethyl acetate fraction of methanolic stem extract of Chenopodium quinoa.

\begin{tabular}{|c|c|c|c|}
\hline Sr. No. & Names of compounds & Known bioactivity & Reference \\
\hline 1 & Phenol,3-methyl- & No activity reported & - \\
\hline 2 & Benzene, nitro- & No activity reported & - \\
\hline 3 & Naphthalene & Antioxidant, antibacterial, & $\begin{array}{l}\text { Shareef et al. (2016), Matsushita et al. } \\
\text { (2011) }\end{array}$ \\
\hline 4 & Tetradecane & Antioxidant, antifungal & $\begin{array}{l}\text { Karpagasundari and Kulothungan } \\
\text { (2014), Mends et al. (2012) }\end{array}$ \\
\hline 5 & Pentadecane & Antioxidant, antimicrobial & $\begin{array}{l}\text { Gnanasundaram and Balakrishnan } \\
\text { (2017), Girija et al. (2014) }\end{array}$ \\
\hline 6 & Cyclohexadecane & $\begin{array}{l}\text { Insecticidal, antioxidant, } \\
\text { anticancer }\end{array}$ & $\begin{array}{l}\text { Habib and Karim (2016), Kumar et al. } \\
\text { (2015) }\end{array}$ \\
\hline 7 & Hexadecane & $\begin{array}{l}\text { Antimicrobial, antioxidant, } \\
\text { anti-inflammatory }\end{array}$ & $\begin{array}{l}\text { Molehin et al. (2017), Das et al. (2016) } \\
\text { Konovalova et al. (2013) }\end{array}$ \\
\hline 8 & $\begin{array}{l}\text { 1,2-Benzenedicarboxylic acid, } \\
\text { bis(2-methylpropyl) ester }\end{array}$ & $\begin{array}{l}\text { Antioxidant, antibacterial, } \\
\text { antifungal }\end{array}$ & $\begin{array}{l}\text { Hifnawy et al. (2016), Al-Youssef and } \\
\text { Hassan (2015) }\end{array}$ \\
\hline 9 & Dibutyl phthalate & Antimicrobial & $\begin{array}{l}\text { Alagammal et al. (2012), } \\
\text { Maruthupandian and Mohan (2011) }\end{array}$ \\
\hline 10 & 1-Nonadecene & Antibacterial, antifungal & $\begin{array}{l}\text { Balachandar et al. (2018), Chowdhary } \\
\text { and Kaushik (2018), Wagay et al. (2017) }\end{array}$ \\
\hline 11 & 1-Octadecanol & Antimicrobial, & $\begin{array}{l}\text { Servi et al. (2019), Chatterjee et al. } \\
(2018)\end{array}$ \\
\hline 12 & 9-Hexacosene & Antibacterial & $\begin{array}{l}\text { Matloub et al. (2018), Gherraf et al. } \\
\text { (2017) }\end{array}$ \\
\hline 13 & $\begin{array}{l}\text { 1,2-Benzenedicarboxylic acid, } \\
\text { mono(2-ethylhexyl) ester }\end{array}$ & $\begin{array}{l}\text { Antifungal, } \\
\text { antibacterial, antiviral, } \\
\text { anticancer, anti-inflammatory }\end{array}$ & $\begin{array}{l}\text { Deepak et al. (2017), Jinfeng et al. } \\
\text { (2017), Ahmed et al. (2015) }\end{array}$ \\
\hline
\end{tabular}

Previously, compounds 9 and 6 have been reported from the ethanolic extracts of Polygala javana and Calotropis gigantea plants with strong antimicrobial and insecticidal activities against Tribolium castaneum pest of stored wheat grains (Alagammal et al., 2012; Habib and Karim, 2016). Likewise, antimicrobial efficacy of compounds 7 and 8 was reported against Aspergillus niger, A. fumigatus, Candida albicans, E. coli, $P$. aeruginosa and S. aureus (Al-Youssef and Hassan, 2015; Das et al., 2016). Gnanasundaram and Balakrishnan (2017) isolated the compound 5 from the ethanolic leaf extract of Cissus vitiginea and reported the antioxidant efficacy along with strong antibacterial potential against S. aureus, K. pneumoniae and E. coli (Girija et al., 2014). Likewise, the antioxidant properties of compound 4 was identified previously and was also found to be effective against pathogenic fungi namely A. flavus and $R$. solani with promising results (Karpagasundari and Kulothungan, 2014; Mends et al., 2012). This study concludes that ethyl acetate fraction of quinoa stem extract is very rich in bioactive compounds especially possessing antimicrobial and antioxidant properties.

Authors' contribution: IHK and AJ conceived and designed the study; IHK conducted the research work and wrote the initial draft; AJ supervised the work, reviewed and edited the manuscript.

Conflict of Interest: The authors declare no conflict of interest.

\section{REFERENCES}

Ahmed, D., Saeed, R., Shakeel, N., Fatima, K., Arshad, A., 2015. Antimicrobial activities of methanolic extract of Carissa opaca roots and its fractions and compounds isolated from the most active ethyl acetate fraction. Asian Pacific Journal of Tropical Biomedicine 5, 541-545.

Akhtar, R., Javaid, A., 2018. Biological management of basal rot of onion by Trichoderma harzianum and Withania somnifera. Planta Daninha 35, e017164713.

Al-Youssef, H.M., Hassan, W.H.B., 2015. Antimicrobial 
and antioxidant activities of Parkinsonia aculeata and chemical composition of their essential oils. Merit Research Journal of Medicine and Medical Sciences 3, 147-157.

Alagammal, M., Tresina, P.S., Mohan, V.R., 2012. GC-MS determination of bioactive components of Polygala javana DC. International Journal of Current Pharmaceutical Research 4, 42-44.

Balachandar, R., Karmegam, N., Saravanan, M., Subbaiya, R., Gurumoorthy, P., 2018. Synthesis of bioactive compounds from vermicast isolated actinomycetes species and its antimicrobial activity against human pathogenic bacteria. Microbial Pathogenesis 121, 155-165.

Chatterjee, S., Karmakar, A., Azmi, S.A., Barik, A., 2018. Antibacterial activity of long-chain primary alcohols from Solena amplexicaulis leaves., Proceedings of the Zoological Society. Springer, pp. 313-319.

Chowdhary, K., Kaushik, N., 2018. Biodiversity study and potential of fungal endophytes of peppermint and effect of their extract on chickpea rot pathogens. Archives of Phytopathology and Plant Protection 51, 139-155.

Das, T.S., Ramesh, L., Agastian, P., 2016. GC-MS analysis of bioactive constituents of Aristolochia bracteolata Linn with in-vitro antioxidant properties. Journal of Applied Pharmaceutical Science 6, 061-066.

Deepak, P., Sowmiya, R., Balasubramani, G., Perumal, P., 2017. Phytochemical profiling of Turbinaria ornata and its antioxidant and anti-proliferative effects. Journal of Taibah University Medical Sciences 12, 329-337.

Gámez, A.L., Soba, D., Zamarreño, Á.M., García-Mina, J.M., Aranjuelo, I., Morales, F., 2019. Effect of water stress during grain filling on yield, quality and physiological traits of illpa and rainbow Quinoa (Chenopodium quinoa Willd.) cultivars. Plants 8, 173.

Gherraf, N., Zellagui, A., Kabouche, A., Lahouel, M., Salhi, R., Rhouati, S., 2017. Chemical constituents and antimicrobial activity of essential oils of Ammodaucus leucotricus. Arabian Journal of Chemistry 10, 2476-2478.

Girija, S., Duraipandiyan, V., Kuppusamy, P.S., Gajendran, H., Rajagopal, R., 2014. Chromatographic characterization and GC-MS evaluation of the bioactive constituents with antimicrobial potential from the pigmented ink of Loligo duvauceli. International Scholarly Research Notices 2014, Article ID 820745, 7 pages.

Gnanasundaram, I., Balakrishnan, K., 2017. Characterization of bioactive compounds in ethanolic extract of Cissus vitiginea leaves using GC-MS Technique. Journal of Applied Chemistry 10, 24-27.

Habib, M.R., Karim, M.R., 2016. Chemical characterization and insecticidal activity of Calotropis gigantea L. flower extract against Tribolium castaneum (Herbst). Asian Pacific Journal of Tropical Disease 6, 996-999.

Hifnawy, M.S., Mohammed, R., Montaser, M., 2016. Chemical composition and anti-microbial activity of the lipoid extract from Portulaca oleracea L. plant, family Portulacaceae. World Journal of Pharmacy and Pharmaceutical Sciences 5, 21012108.

Jinfeng, E.C., Ikhtifar, M., Rafi, M., Hoon, K.C., Lian, H.K., Kqueen, C.Y., 2017. Analysis of chemical constituents, antimicrobial and anticancer activities of dichloromethane extracts of Sordariomycetes sp. endophytic fungi isolated from Strobilanthes crispus. World Journal of Microbiology and Biotechnology 33, 5-24.

Karpagasundari, C., Kulothungan, S., 2014. Analysis of bioactive compounds in Physalis minima leaves using GC MS, HPLC, UV-VIS and FTIR techniques. Journal of Pharmacognosy and Phytochemistry 3, 196-201.

Konovalova, O., Gergel, E., Herhel, V., 2013. GC-MS analysis of bioactive components of Shepherdia argentea (Pursh.) Nutt. from Ukrainian Flora. The Pharma Innovation Journal 2, 7-12.

Kumar, D.R.N., George, V.C., Suresh, P.K., Kumar, R.A., 2015. Cancer-specific chemoprevention and antimetastatic potentials of Rheum emodi rhizome ethyl acetate extracts and identification of active principles through HPLC and GC-MS analysis. Pakistan Journal of Pharmaceutical Sciences 28, 83-93.

Maliro, M., Njala, A.L., 2019. Agronomic performance and strategies of promoting Quinoa (Chenopodium quinoa Willd) in Malawi. Ciencia e Investigación Agraria 46, 82-99.

Maruthupandian, A., Mohan, V.R., 2011. GC-MS analysis 
of some bioactive constituents of Pterocarpus marsupium Roxb. International Journal of ChemTech Research 3, 1652-1657.

Matloub, A.A., Mohammed, R.S., Elsouda, S.S., El-Hallouty, S.M., Gomaa, E.Z., Hassan, A.A., 2018. Phytochemical and biological studies on Enterolobium contortisiliquum (Vell.) Morong Pericarps. Journal of Materials and Environmental Sciences 9, 2768-2778.

Matsushita, Y., Jang, I.-C., Imai, T., Fukushima, K., Lee, J.M., Park, H.-R., Lee, S.-C., 2011. Antioxidant and cytotoxic activities of naphthalene derivatives from Diospyros kaki. Journal of Wood Science 57, 161-165.

Meela, M.M., Mdee, L., Masoko, P., Eloff, J.N., 2019. Acetone leaf extracts of seven invasive weeds have promising activity against eight important plant fungal pathogens. South African journal of botany 121, 442-446.

Mends, M.T., Yu, E., Strobel, G.A., Riyaz-Ul-Hassan, S., Booth, E., Geary, B., Sears, J., Taatjes, C.A., Hadi, M.Z., 2012. An endophytic Nodulisporium sp. producing volatile organic compounds having bioactivity and fuel potential. Journal of Petrolium and Environmental Biotechnology 3, 1000117.

Molehin, O.R., Oloyede, O.I., Ajayi, E.I., 2017. GC-MS analysis of bioactive compounds in three extracts of Clerodendrum volubile P. Beauv leaves. Journal of Medicinal Plants Studies 5, 191-195.

Pereira, R.M., Greco, G.M., Moreira, A.M., Chagas, P.F., Caldas, I.S., Goncalves, R.V., Novaes, R.D., 2017.
Applicability of plant-based products in the treatment of Trypanosoma cruzi and Trypanosoma brucei infections: a systematic review of preclinical in vivo evidence. Parasitology 144, 1275-1287.

Servi, H., Keskin, B.E., Yilancioglu, K., Celik, S., 2019. Essential oil composition and antibacterial activities of Gypsophila species. International Journal of Secondary Metabolites 6, 20-27.

Shareef, H.K., Muhammed, H.J., Hussein, H.M., Hameed, I.H., 2016. Antibacterial effect of ginger (Zingiber officinale) and bioactive chemical analysis using gas chromatography mass spectrum. Oriental Journal of Chemistry 32, 817-837.

Vergara, R.O., Martins, A.B.N., Pedo, T., Radke, A.K., Gadotti, G.I., Villela, F.A., Meneguzzo, M.R.R., 2019. Plant growth and physiological quality of quinoa (Chenopodium quinoa Willd) seeds grown in southern Rio Grande do Sul, Brazil. Australian Journal of Crop Science 13, 678.

Wagay, N.A., Khan, N.A., Rothe, S.P., 2017. Profiling of secondary metabolites and antimicrobial activity of Crateva religiosa G. frost bark. A rare medicinal plant of Maharashtra India. International Journal of Biosciences 10, 343-354.

Waltenberger, B., Halabalaki, M., Schwaiger, S., Adamopoulos, N., Allouche, N., Fiebich, B., Schönbichler, S., 2018. Novel natural products for healthy ageing from the mediterranean diet and food plants of other global sources-the medihealth project. Molecules 23, 1097. 